\title{
Effectiveness of Community-Based Disaster Management in Cabanatuan City
}

\author{
Kim Edward S. Santos \\ Nueva Ecija University of Science and Technology Philippines \\ *Corresponding author: Kim Edward S. Santos; kimnyte@ gmail.com
}

Received 05 January 2020; $\quad$ Accepted 12 January 2020;

Published 16 January 2020

\begin{abstract}
Disasters in the Philippines serve as great vanguards defying all existing social divisions and stratifications, influencing all, and uniting communities across boundaries in order to prepare and prevent it. This study focused on the Community Based Disaster Management in selected barangays of Cabanatuan City. The main problem of the study is to determine the effectiveness of Community Based Disaster Management. The respondents of the study were 100 residents and was conducted at ten (10) selected barangays of Cabanatuan City namely: Aduas Centro, Aduas Norte, Aduas Sur, Isla, Sumacab Este, Sumacab Norte, Sumacab Sur, Pagas, Kapitan Pepe, and Valdifuente. The researcher used descriptive method of research. The findings of the study were: early delivery of warning that affects the alertness of the residents had been confirmed effective by the most of the respondents; the prevention and minimizing the impact of natural disasters made by the barangay were properly prepared and necessary actions were taken properly. In terms of conducting short term recovery, there is a sufficient supply of relief goods that helped the respondents to recover faster and the rescue team conducts their job without further delay.
\end{abstract}

Keywords: Disaster, Disaster Management, Early Delivery, Rescue, Prevention, Community-Based

\section{INTRODUCTION}

Disasters in the Philippines serve as great vanguards defying all existing social divisions and stratifications, influencing all, and uniting communities across boundaries in order to prepare and prevent it. It is known that the Philippines is one of the world's most disaster-prone countries (Maceda et al., 2009). Victoria (2003) stated that the Philippines ' experience of repeated disasters and a long history of community self-help activities encouraged Community-based Disaster Management's adoption. Further, Gero et al. (2011) stated that academics and development practitioners recognize that many common strategies to address communitybased disaster risk reduction and adaptation to climate change duplicate one another.

According to Shaw (2012), Communities are at the heart of disaster risk reduction, and community-based approaches are becoming increasingly focused on national disaster risk reduction plans as they have always been first responders and have taken leadership roles in post-disaster recovery. Thus, Walia (2008) concluded that the community-based disaster risk reduction delivery faces various challenges including duplication of effort, lack of training requirements, lack of coordination, local resource alignment, and lack of trained experts to communicate with and support local populations.
Chen, Liu and Chan (2006) concluded that through a participatory process, members of the city have learned how to evaluate fragile situations, identify challenges, develop solutions, and build a disaster management agency. Moreover, Motoyashi and Ikeda (2004) further explained that the social standard and flood concern contributed positively to the decision to engage in a disaster preparedness scheme focused on the community.

In light of the foregoing insights, the researcher then piqued his interest in assessing the effectiveness of community-based disaster management in Cabanatuan City. The purpose of this study is to determine the CBDM's approach effectiveness prior to and after the disaster occurrence.

\section{CONCEPTUAL FRAMEWORK}

Motoyoshi (2006) concluded that people are more willing to engage in community-based disaster preparedness programs when they are very interested in subjective standards and flood hazards.

Evidenced by Allen (2006) from the Philippines that Community-Based Disaster Preparedness programs have the ability to motivate and disempower and advise against viewing Community-Based Disaster Preparedness as a panacea to disaster management problems in the restricted ways in which they are currently employed.

This study is mainly anchored on the published researched paper of Pandey and Okazaki (2005). As they concluded that the 
Community-Based Disaster Management improves the ability of individuals to respond to emergencies by providing them with more access and control over infrastructure and basic social services.

\section{OBJECTIVES OF THE STUDY}

The study described the effectiveness of community based disaster management in terms of Early delivery of warning, prevention and minimizing the impact of natural disasters, and, conducting shortterm recovery period.
The is study used the descriptive method of research. The main objective of the study is to explore the causes of particular phenomenon. It further concern with the condition or relationship that exists; practices that prevail; and beliefs and processes that are going on; effects that being felt or trends that are developing. (Cohen, Manion, Morrison, 2002)

The researcher used likert-scale type questionnaire (Vagias, 2006) and analyzed it through statistical data treatment such as mean and weighted mean.

\section{METHODOLOGY}

\section{Table 1: Early Delivery of Warnings}

\begin{tabular}{|l|l|l|}
\hline & Weighted Mean & Verbal Interpretation \\
\hline The warning of fortuitous event is just in time. (prior to the occurrence) & 4.46 & Agree \\
\hline The equipment used in delivering warning is effective. & 4.14 & Agree \\
\hline There is a proper dissemination of the evacuation program. & 4.02 & Agree \\
\hline The residents were oriented and followed the given instructions and warnings. & 4.15 & Agree \\
\hline The evacuation plan was implemented prior to the warning. & 4.07 & Agree \\
\hline
\end{tabular}

Table 1 showed that "The warning of fortuitous event is just in time. (prior to the occurrence)" has a weighted mean of 4.46 and verbal interpretation of agree, "The equipment used in delivering warning is effective" has a weighted mean of 4.14 and a verbal interpretation of agree, "There is a proper dissemination of the evacuation program." has a weighted mean of 4.02 and a verbal

\section{RESULTS}

Table 2: Prevention and Minimizing the Impact of Natural Disaster

\begin{tabular}{|l|l|l|}
\hline & Weighted mean & Verbal Iterpretation \\
\hline The Barangay has plans and programs for fortuitous events. & 4.00 & Agree \\
\hline The conducted seminars is helpful to the people in the Barangay to minimize casualties. & 3.90 & Agree \\
\hline There is a monthly conducted meeting of Barangay officials and its residents. & 3.93 & Agree \\
\hline There are different plans addressing different types of natural disaster. & 4.00 & Agree \\
\hline There is a conducted seminar about different natural disasters. & 4.01 & Agree \\
\hline
\end{tabular}

Table 2 showed that "The Barangay has plans and programs for fortuitous events" has a weighted mean of 4.00 and a verbal interpretation of agree, "The conducted seminars is helpful to the people in the Barangay to minimize casualties" has a weighted mean of 3.90 and a verbal interpretation of agree, "There is a monthly conducted meeting of Barangay officials and its interpretation of agree, "The residents were oriented and followed the given instructions and warnings" has a weighted mean of 4.15 and a verbal interpretation of agree, "The evacuation plan was implemented prior to the warning" has a weighted mean of 4.07 and a verbal interpretation of agree.

\section{Table 3: Conduct a Short-term Recovery Period}

\begin{tabular}{|l|l|l|}
\hline & Weighted Mean & Verbal Interpretation \\
\hline There are enough supplies of relief goods for the residents of the Barangay. & 3.84 & Agree \\
\hline There is a seminar for recovery after the disaster took place. & 3.88 & Agree \\
\hline The number of rescue team are enough to help the residents. & 3.84 & Agree \\
\hline The rescue team conducts their job actively without further delay. & 3.81 & Agree \\
\hline Evacuation of the residents were properly done in compliance to safety and security. & 3.81 & Agree \\
\hline
\end{tabular}

Table 3 showed that "There are enough supplies of relief goods for the residents of the Barangay" has a weighted mean of 3.84 and the verbal interpretation of agree, "There is a seminar for recovery after the disaster took place" has a weighted mean of 3.88 and a verbal interpretation of agree, "The number of rescue team are enough to help the residents" has a weighted mean of 3.84 and verbal interpretation of agree, "The rescue team conducts their job actively without further delay" has a weighted mean of 3.81 and a verbal interpretation of agree, "Evacuation of the residents were properly done in compliance to safety and security" has a weighted mean of 3.81 and a verbal interpretation of agree.

\section{CONCLUSION AND DISCUSSION}

residents." has a weighted mean of 3.93 and a verbal interpretation of agree, "There are different plans addressing different types of natural disaster" has a weighted mean of 4.00 and a verbal interpretation of "Agree", and "There is a conducted seminar about different natural disasters" has a weighted mean of 4.01 and a verbal interpretation of agree.
Early delivery of warning that affects the alertness of the residents had been confirmed effective by the most of the respondents. Results shows that the prevention and minimizing the impact of natural disasters made by the barangay are properly prepared and necessary actions were taken properly. In terms of conducting short term recovery period there is a sufficient supply of relief goods that helps the residents to recover faster and the rescue team conducts their job without further delay. Thus, effective training is needed to improve the performance of the rescue team and incentives might also be used in improving it.

\section{Data Availability}


All relevant data are within the paper and its supporting information files.

\section{Conflicts of Interest}

The author declared that there is no conflict of interest regarding the publication of this paper.

\section{Funding Statement}

The author didn't receive any specific funding for this work.

\section{REFERENCES}

[1] Allen, K. M. (2006). Community-based disaster preparedness and climate adaptation: local capacity-building in the Philippines. Disasters, 30(1), 81-101.

[2] Chen, L. C., Liu, Y. C., \& Chan, K. C. (2006). Integrated community-based disaster management program in Taiwan: a case study of Shang-An village. Natural Hazards, 37(1-2), 209.

[3] Cohen, L., Manion, L., \& Morrison, K. (2002). Research methods in education. routledge.

[4] Gero, A., Méheux, K., \& Dominey-Howes, D. (2011). Integrating community based disaster risk reduction and climate change adaptation: examples from the Pacific. Natural Hazards and Earth System Sciences, 11(1), 101-113.

[5] Maceda, E. A., Gaillard, J. C., Stasiak, E., Le Masson, V., \& Le Berre, I. (2009). EXPERIMENTAL USE OF
PARTICIPATORY 3-DIMENSIONAL MODELS IN ISLAND COMMUNITY-BASED DISASTER RISK MANAGEMENT. Shima, 3(1).

[6] Motoyoshi, T. (2006). Public perception of flood risk and community-based disaster preparedness. A better integrated management of disaster risks: Toward resilient society to emerging disaster risks in megacities. Tokyo, Japan: Terrapub, 121-134.

[7] Motoyoshi, T., Takao, K., \& Ikeda, S. (2004). Determinant factors of community-based disaster preparedness: A case study of flood prone area. Shinrigaku kenkyu: The Japanese journal of psychology, 75(1), 72-77.

[8] Pandey, B. H., \& Okazaki, K. (2005). Community-based disaster management: empowering communities to cope with disaster risks. Regional Development Dialogue, 26(2), 52.

[9] Shaw, R. (Ed.). (2012). Community based disaster risk reduction. Emerald Group Publishing.

[10] Vagias, W. M. (2006). Likert-type scale response anchors. clemson international institute for tourism. \& Research Development, Department of Parks, Recreation and Tourism Management, Clemson University.

[11] Victoria, L. P. (2003). Community-based disaster management in the Philippines: making a difference in people's lives. Philippine Sociological Review, 51, 65-80.

[12] Walia, A. (2008). Community based disaster preparedness: Need for a standardized training module. Australian Journal of Emergency Management, The, 23(2), 68. 